\title{
China's rising middle class: A case study of Shanghai college students
}

Joseph C. Morreale

Department of Economics, Pace University

USA

jmorreale@pace.edu

\author{
Anna Shostya \\ Department of Economics, Pace University \\ USA \\ ashostya@pace.edu

\section{Mariana Villada} \\ Department of Economics, Pace University \\ USA \\ mv09509n@pace.edu
}

Abstract. One of the hotly debated questions in socio-economic literature is the one pertaining the rise of the middle class in China and its potential influence on political and social structures. This paper is a study of the perceptions of Chinese young adults on the rise of the middle class in China. We address such questions as: How do university students in China define the middle class and perceive its growth? How do they see future economic, political and social changes in China? We conducted the survey case study of 204 Chinese undergraduate students at a major university in Shanghai. Our results show that the students have a strong belief in the rise of the middle class in China. They expect this rise to affect China's economic structure to a larger extent than the social and political order. We conclude that the surveyed Chinese college students may belong to what is called - "Generation 2": they are confident, independent minded and determined to display that independence through their consumption of Western products. The results of our survey are compared and contrasted to the findings of the national surveys addressing similar questions.

Keywords: China, youths' perceptions, college students in Shanghai, middle class, attributes of middle class, economic, social and political changes.

JEL Classification: D31, O53, P20 


\section{INTRODUCTION}

In March of 2013, The New Yorker magazine published an article with the forward-looking title "Will the Middle Class Shake China?" (Osnos, 2013). The theme of the article centered on the influence of the rise of China's growing middle class and its potential impact on the economic system and political relations within the nation. Since 2013, China's economy has grown by about $17 \%$, becoming a leading economy by many accounts (World Bank database, 2018). Its real Gross Domestic Product (GDP) in Purchasing Power Parity (PPP) overtook that of the USA and was estimated to be almost $\$ 20$ trillion dollars in 2016 (see Chart 1 below). This impressive economic growth has lifted millions people out of poverty and for the first time in China's history created a massive middle class. Although there is no standard way to measure the middle class, according to some estimates, the size of the new middle class in China was around $225 \mathrm{mln}$ households in 2016, as compared with just $5 \mathrm{mln}$ back in 2000 and is been predicted to be about 275 million households by 2020 (The Economist, July 9 $9^{\text {th }}$, 2016). These households make the annual income of 75,000-280,000 yuan ( $\$ 11,500-43,000$ ), are highly concentrated in urban areas and enjoy their own homes (around $80 \%$ of them own property, according to the Economist, July 9th 2016 ). They drive their own cars and send their kids to study abroad. Thus, the existence of the middle class in China is a testament to the remarkable economic growth and development and quite high standards of living. Yet, historically, development of the middle class is not merely about the rise in affluence.

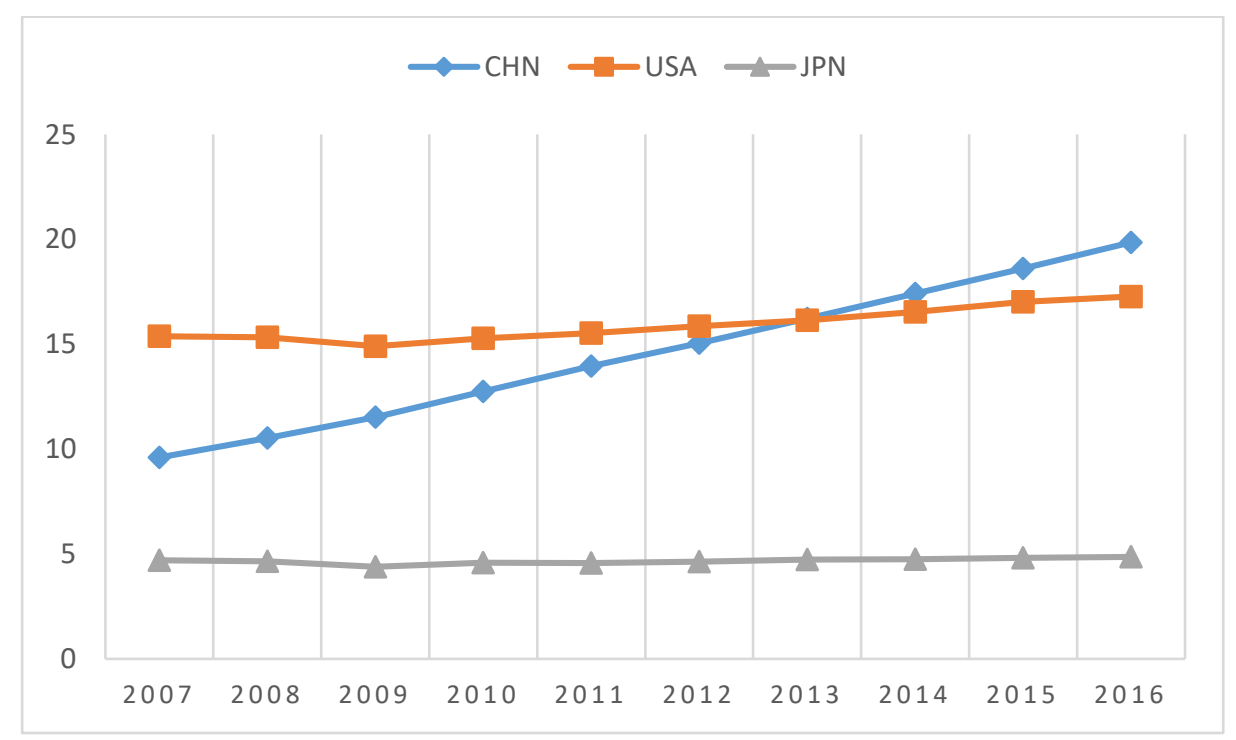

\section{Chart 1. Purchasing Power Parity of Gross Domestic Products, (constant 2011 International \$, trillions)}

Source: World Development Indicators, World Bank database.

In the West, the middle class has been considered to be an agent of the socio-political movement toward democratic rule and an active participant in the public decision-making process (Chen and Lu, 2016). Members of the middle classes in the USA, Germany, the United Kingdom, and other advanced countries do not just have better jobs, are more educated, and enjoy higher standards of living than their less fortunate counterparts. They also place a larger emphasis on non-material values, including political choice and participation in governance. They have had a strategic role in shaping the democratic political system and its principles. China's emerging middle class has become a major topic of discussion by academics and policy makers because of this potential influence on the political structure. But it is not clear if the development 
of the middle class in China will follow the Western path. Political scientists, economists, and sociologists have many questions. What will the rise of the middle class mean to the future of Chinese economic development? Will the rising middle class bring forth political and economic reforms to modernize and liberalize Chinese society? Will the expansion of the Chinese middle class be continuous and sustainable? The answers to these questions depend on how China's newly educated youth perceive their role and future in the middle class in China. It is the role of their expectations that drives the future of the middle class in China and shapes political, economic, and social changes in the country.

Although there have been many studies that try to define and measure the middle class in China and there have been a large number of studies that explore the relationship between the rise in the middle class and the likelihood of the democratization of China's political system, there have been no studies that would target Chinese educated youth in particular. Our study contributes to the exploration of this question, "How would China's growing middle class, and specifically its educated youth, impact China politically, socially and economically?" We believe that the literature on the middle class leaves much to be desired, especially about the changing attitudes and desires of a new generation. Yet, it is their expectations that drive the future of the middle class in China and thus shape China's future political, economic, and social landscape.

The major objective of this paper is to measure the perceptions of China's educated youth on the rising middle class in China. We distributed a 20 question survey to 204 Chinese undergraduate students at a major urban university in Shanghai to probe their views of the growing middle class. The results reveal a number of important perceptions that Chinese students have of their own and their nation's future. This case study of college students in Shanghai is important because today's educated youth in China are most likely to become part of the future middle class. Our hypothesis is that China's educated young people perceive the rise of the middle class to be associated more with economic changes and less with political or social ones. This might mean that the development of the middle class in China might follow a different path than that in the West. It may take a much longer time for the Chinese middle class to become a harbinger of democratic changes.

The paper will follow with six sections. The next section discusses key studies in the literature pertaining to our topic. The following section discusses the methodology used in the analysis. The fourth section presents the results of our survey of our student sample. The fifth section compares and contrasts our results with those of other surveys probing answers to similar questions. The following section compares and contrasts the rise of the middle class in Western countries in the past with the rise of the middle class in China today. The last section concludes and discusses potential implications of the rise of the middle class in China.

\section{LITERATURE REVIEW}

\subsection{Definition of the middle class}

Previous studies (Eulau, 1956; Nie et al., 1969; Verba \& Nie, 1972; Sherkat \& Blocker, 1994; Goodman, 1999; Walsh et al., 2004; Johnston, 2004; Chen \& Lu, 2011; Chen, 2013; Goodman, 2016) indicate that there are two approaches to the definition of the middle class: subjective and objective. Supporters of the subjective approach believe that a social class is part of the individual's overall psychological self-concept (Centers, 1949; Eulau, 1956; Walsh et al., 2004) and as such it is based on the way individuals think of themselves as a social group. This psychological attachment affects the people's political beliefs and attitudes towards the economy, politics and political leadership, and the social structure.

Supporters of the objective approach argue that the middle class should be defined based on certain socio-economic attributes, such as education, income, occupation, and apartment ownership (Alford, 1962; 
Verba \& Nie, 1972; Wright, 1997; Chen \& Lu, 2006; Chen, 2013;). There are two branches within this approach: the quantitative branch and the qualitative branch. The "quantitative" branch identifies the middle class through a vector of quantitative variables, such as income, education, and occupation (Nie, et al., 1969; Verba \& Nie, 1972; Sherkat \& Blocker, 1994; Goodman, 1999; Johnston, 2004). The "qualitative" branch, based mostly on a neo-Marxist platform, assumes that the middle class possesses certain means of production and thus, by definition, includes the petite bourgeoisie, managers, and professionals (Burris, 1986; Glassman, 1995; Wright, 1997). Xueyi Lu et al. (2002 and 2004) as cited by Chen (2013) offer a stratification system by occupation, based on four dimensions: means of production ownership, level of authority, human capital ownership, and position in the political sphere (see Chen, pages 38-39, for a detailed systematic table). Chen and $\mathrm{Lu}$ (2006) suggest a three-prong occupation stratification: private entrepreneurs of small and medium size firms, managers, and white-collar professionals.

There are a lot of debates, however, within both branches. Although income has often been cited as the most common measurement of the middle class (Goodman, 1999; Johnston, 2004), many scholars find income to be an unreliable and often misleading indicator of middle class membership (Shi, 1997; Chen, 2004; Wang \& Davis, 2010; Chen, 2013). Chen (2013), for example, argues that a) many incomes go unreported; b) in China formal wages "do not necessarily represent a person's real socioeconomic status" (35); and c) income levels vary widely geographically. Yet Chen chooses the objective approach because he believes that "the class consciousness of the Chinese middle class is still in formation" (33). In his study, few respondents identified themselves as "upper class," "middle class" or "lower class." Well educated people seem more likely to identify themselves as government officials, private entrepreneurs, or professionals. Poorly educated people seem to draw the distinction between "rich people," "powerful people" and "ordinary people" (Chen, 2013).

Yang (2010) who also supports the objective approach divides the middle class into three major groups: new middle class, old middle class and marginal middle class. The new middle class is composed of party and government officials, enterprise managers and private entrepreneurs, professionals and senior level clerical workers. The old middle class refers to traditionally self-employed people. The marginal middle class consists of lower/entry level clerical workers and employees in the sales and service sectors. Yet other researchers propose a multidimensional approach to define and measure middle class in China and use occupation, income, consumption, and self-identification to calculate the size of the middle class (Li, 2010).

Barton, Chen, and Jin (2013) emphasize the need to realize that there is a separately developing upper middle class from the overall middle class. This latter group is "poised to become the principle engine of consumer spending over the next decade" (2). In fact, some researchers suggest a consumption curve as an analytical tool to define and measure the middle class in China (Silverstein et al., 2012). Xiaohong and Chen (2010) believe that an increase in consumption is not only a sign of the increased wealth but also a signal of self-identity and social recognition. Song et al. (2016) support the idea of consumption as one of the dimensions to the definition of the middle class. The authors construct a social stratification system that identifies the factors by which the middle-class households vary or are similar in their consumption behavior. They find that out of the three recognized stratifying dimensions (income, education, and occupation), education attainment seems to be the strongest class indicator explaining the variance in consumption among the middle class households.

\subsection{The Emergence of the Middle Class in China}

In the pre-Communist era, the middle class in China was in an infantile stage, due to the lack of wellestablished capitalism as an economic system and the absence of independent entrepreneurial power during the late $19^{\text {th }}$ and early $20^{\text {th }}$ centuries (Fairbank, 1983). The situation has not changed much after the Maoist 
revolution. Those few private entrepreneurs and petty-bourgeoisie who enjoyed the benefits from the limited private sector prior to the 1949 were crushed under the political and economic grip of the new Communist rule (Bergere, 1989). In fact, the four million private enterprises that had existed in China before 1949 had been dismantled by the mid-1950s (Li, 2010). The term middle class was not allowed during the years of the Mao Zedong rule (1949-1976). Maoist ideology officially declared the existence of only three social strata - peasants, workers, and intellectuals, with the latter one being of little resemblance to the Western notion (with Marxist roots) of the middle class (Li, 2010).

Deng Xiaoping who became the leader of China is 1978, initiated partial market liberalization and proclaimed that getting rich is not a sin. He thus opened opportunities for private enterprise and profit, especially in the country side. The earliest use of the concept of the middle class was in reference to rural industrialists and to a limited extent private enterprises in the urban areas (Li, 2010). Still, until the very end of the $20^{\text {th }}$ century, Chinese officials preferred to refer to the middle class as the middle-income class or the middle stratum, i.e. a population that enjoys average earnings (Ekman, 2014). After denouncing bourgeois values for decades, the Chinese government was reluctant to officially admit that the rising entrepreneurs, private investors, and merchants were the driving force of the economic growth (Osnos, 2013).

The $21^{\text {st }}$ century has brought a "need" for the middle class concept. In fact, in his 2002 speech, President Jiang Zemin placed a special emphasis on the growth of the "new middle-propertied stratum" (Osnos, 2013). Why was suddenly there a need for the middle class in China? Historically, China as a nation has always put a special emphasis on stability, order, and respect to authority. These values have been rooted in the long-standing ancient tradition of Confucianism that is so deeply ingrained in Chinese culture. Confucius (551 BC - 479 BC), a prominent philosopher and perhaps the most influential figure in China's history, preached obedience, respect, and conformity. The middle class that enjoys a high standard of living may still hold these values and thus is not likely to initiate any drastic political reforms. Thus by promoting middle class values, the government may, in fact, promote order and conformity. In addition, the idea of a large middle class also has been the primary driver of foreign direct investment and local business activities. China has been enjoying one of the highest savings rates and the largest potential consumer base in the world, both of which provide enormous opportunities to the business community, both domestically and abroad (Li, 2010).

Yet, studies indicate that even though the middle class in China may look like the middle classes in the West, it has unique characteristics and thus may be very different from its Western antecedents (Chen, 2013; Engelhart, 20013). The main difference is that China's new middle class has been heavily reliant on the state for its survival and growth (Chen, 2013). Research shows that in the late-developing countries, the middle class is most likely to be "illiberal" and "undemocratic" and generally supports the state and its policies (Johnson, 1985; Brown \& Jones, 1995; Englehart, 2003; Davis, 2004). This is because the middle class depends on the state's power to survive and prosper. Chen (2013) for example, concludes that the socioeconomic conditions of a late developing country create a need for a strong state. He further argues that in comparison to other late developers, the Chinese government traditionally seems to have a stronger propensity to penetrate society in general and to initiate and facilitate economic reforms in particular. This is mainly resulting from two sources: the state's control over national financial resources and the state's somewhat monolithic organizational structure controlled by the Communist Party.

\subsection{Economic, Political and Social Changes and the Rise of a Middle Class}

Another hotly debated question in discussing the rise of the middle class in China is its potential influence on political and social structures and systems. Some authors argue that the middle class is not strong enough to change China's political order (Ekman, 2015; Goodman, 2016). This is because most of 
the Chinese middle class appears to be politically conservative and has a vested interest to not challenge the current political system. On the contrary, Blau (2016) believes that the middle class is going to change China's intellectual landscape, as its members become more individualistic and invest in new opportunities.

Scholars also disagree about the relationship between the rising middle class and the growth of democracy. Some take the unilinear approach that emphasizes the relationship between economic modernization and political democratization (Chen \& Lu, 2011). It rests on the view that as the middle class increases, the levels of income, education, social mobility and the valuation of freedom increase. All of these attributes may form a foundation for the development of a democratic society. Many studies suggest that the middle class may become a harbinger of democracy (Eulau, 1956; Lipset, 1981; Moore, 1993; Walsh et al., 2004). They state that the middle class develops an awareness that its ability to maintain its status and economic footing in the society hinges on the protection of its individual rights, particularly for the ownership of property, the key to their wealth and success. Being more aware of their political efficacy, the members of the middle class may then act on these beliefs (Eulau, 1956, Verba \& Nie, 1972). Many western authors argue that the middle class, being empowered by education and having a sufficient amount of free time, is then capable of participating in public affairs in a more effective way (Mills, 1953; Eulau, 1956; Lipset, 1959; Nie et al., 1969; Dahl, 1971; Lipset, 1981; Glassman, 1995; Glassman, 1997; Walsh et al., 2004).

Instead of assuming a linear relationship of middle class growth to democratic development, the contingent approach suggests a much more dynamic nature of the relationship between modernization and democratization. This approach does not assume that democratization is the inevitable outcome of economic growth of the middle class. Instead, it sees this development as contingent on important socioeconomic and political conditions, such as the relationship of the middle class to the state, political alliances with other classes, its own self-identity and class cohesiveness, and its fear of political instability (Huntington, 1993; Dickson, 2003). Goodman (2016) supports this approach emphasizing that because of the close association of the professional middle-class with the Party-State, it seems unlikely that there would be any regime change.

\section{METHODOLOGY}

We created a questionnaire to survey undergraduate students at the University of Shanghai for Science and Technology (USST) on their perception of the middle class and its potential impact on the economic, political and social structures in China. The Chinese students (ranging from freshmen to seniors) were enrolled in a bilingual academic program focused on business, financial management and international trade. The survey instrument consisted of 20 closed questions with multiple choice answers. We first validated the questionnaire by giving it a pilot test with 25 randomly selected Chinese undergraduates. We were particularly concerned about the students' understanding of concepts in the survey, especially the ones related to the definition of the middle class. We found that the student pilot sample understood the questions presented and the answers showed agreement on the definitions of the ideas presented (See a copy of the survey in the Appendix).

In 2016, we administered the survey to 250 USST students, but only 204 were used for the final tabulations, as 46 students omitted some of the questions. It was a random sample, which consisted of $71 \%$ females and $29 \%$ males. The overrepresentation of females was due to the traditional population break down on the campus. Because the students at this university are required to take intensive English Language coursework in their freshman year, prior to their enrollment in business/economics courses, no freshmen could participate in the study. About three-fourth of the students who completed the survey came from other cities to study in Shanghai. 
The survey answers were compiled as a percentage breakdown of the answers provided by the respondents. We also created intensity of response indices for three important questions that assessed the students' perceptions of attributes of Middle Class, their Life Goals and Factors that lead to Financial Success (Q11, Q14 and Q15 in the survey, see Appendix). Responses of "very important," "somewhat important" and "not important" were weighted 2, 1, and 0, respectively, and the weighted average was calculated, which we called the "intensity index". We ran standard non-parametric tests to check the validity and significance of the responses. We used Chi-square test for the bivariate relations between nominal variables, Kruskal-Wallis test for the relationships between ordinal and nominal variables, and Pearson correlation test for ratio variables.

\section{EMPIRICAL RESULTS AND DISCUSSION}

We began the survey by asking some family background questions. Given the importance of the educational level in being middle class, we asked the students about their parents' level of education. Almost two-thirds $(63 \%)$ came from families where both parents had a university degree. Twelve percent said only their father had the degree and 7\% said that only their mother held a degree. We also asked the students about the type of work their parents were engaged in. About one-third (32\%) said that one parent worked for a private company and the other parent worked for a state-owned company or government. Almost one-quarter $(24 \%)$ answered that both parents worked for a government or a state owned company; almost another quarter $(22 \%)$ revealed that one of their parents owned his/her own business; and only $21 \%$ answered that both of their parents worked for private companies.

The question about the family's perceived social class was most revealing. We gave the students five choices: upper class, upper-middle class, middle class, lower middle class and lower class. About half of the students $(48 \%)$ believed that their family was middle class; about a quarter $(24 \%)$ thought they were lower middle class; and 19\% percent considered their family to be upper middle class. Only 5\% thought they were lower class and $4 \%$ said that their families were upper class. The Chi-square test indicated that there is a statistically significant relationship between the students' perception of the family's status and whether or not their parents had a university degree $(p$-value $=0.011)$. The test also indicated that there is a statistically significant relationship between the students' perception of the family's status and their parents' type of job $(\mathrm{p}$-value $=0.004)$. Both results were expected.

We then asked the critical question of their definition of "middle class." About two-fifths of the respondents $(42 \%)$ thought that both level of education (university degree) and median income or above defined the middle class. Only one-quarter (26\%) focused on households having incomes around the median income level of Chinese households. The Pearson correlation test indicated a strong significant difference between these two choices (Pearson's $r=0)$. About one-fifth $(18 \%)$ simply defined it as "those households between the upper and lower income classes." Ten percent defined the middle class as being headed by a professional or business owner. Only four percent of the respondents thought of the middle class as "the middle 50 percentile of the income classes." The Chi-square test suggested that there is no significant relationship between the students' view of the middle class and their parents' job types ( $\mathrm{p}$-value is 0.235 ). These results show that college students felt that education and level of income are more characteristic of the middle class than profession or occupation.

We then asked a series of questions to gauge the importance of various attributes of the middle class. We offered nine choices (attributes) that help define the middle class (Q11). We used the intensity index to gauge the strength of the students' responses. As can be seen from the intensity index averages (Table 1), to own a home/apartment, to have a secure job, and to have health insurance were perceived to be the most important attributes (the values were 1.76, 1.71 and 1.61, respectively). Another question (Q14) probed the 
relative importance of different life goals to the students. We found that the four highest ranked life goals were: a good family, good relationship with friends, gain knowledge of new things, and own a house or apartment (the values of the intensity index were 1.83, 1.76, 1.65 and 1.57, respectively; Table 2). "Doing something important for my country" was least important (1.16).

Table 1

Perceived Attributes of the Middle Class (Intensity Index)

\begin{tabular}{|l|c|}
\hline To own a home/apartment & 1.76 \\
\hline To own a car & 1.30 \\
\hline To have a secure job & 1.71 \\
\hline To have a college education & 1.26 \\
\hline To own stocks, bonds or other & 0.96 \\
\hline To have health insurance & 1.61 \\
\hline To be able to buy designers clothes/accessories & 0.91 \\
\hline To have the ability to travel a lot & 1.12 \\
\hline To have the freedom to do what I want & 1.43 \\
\hline
\end{tabular}

Sources: Authors' calculations

Table 2

Personal Life Goals (Intensity Index)

\begin{tabular}{|l|l|}
\hline A good family & 1.83 \\
\hline Wealth & 1.22 \\
\hline A stable job & 1.48 \\
\hline Knowledge of new things & 1.65 \\
\hline An ownership of a house/apartment & 1.57 \\
\hline Good relationships with friends & 1.76 \\
\hline Doing something important for my country & 1.16 \\
\hline
\end{tabular}

Sources: Authors' calculations

An additional question (Q15) asked about the students' perceived keys to financial success. Given the intensity index results, there were three that were most important: hard work and determination, family and friends connections, and education (the values were 1.78, 1.67 and 1.54, respectively; Table 3). This reflects the traditional view that emphasizes the importance of family and friends, hard work and education. In contrast, party membership was given the lowest priority of all (1.03). This result is consistent with the recent report from the Chinese Academy of Social Sciences that found that party membership does not necessarily guarantee better employment prospects (The Economist, 22 February 2014).

We were also interested in how students perceive their future standard of living relative to that of their parents when they were of the same age (Q8). We found that two-thirds $(65 \%)$ of the students believed that they were much better off than their parents. About another one-fifth $(22 \%)$ said they were somewhat better off. The Pearson correlation test indicated that there is a significant difference between these two responses (Pearson's $r=0$ ). Yet, 7\% thought they were either worse off or much worse off. Six percent thought they were about the same. The Kruskal-Wallis test suggested that there is no significant difference between the students' perception of their families' social class and their view of their standard of living as compared to that of their parents ( $\mathrm{p}$-value 0.246$)$. 
Perceived key to financial success in China (intensity index)

\begin{tabular}{|l|l|}
\hline Hard work and determination & 1.78 \\
\hline Family/Friends Connections & 1.67 \\
\hline Initial monetary endowment & 1.31 \\
\hline Education & 1.54 \\
\hline Luck & 1.39 \\
\hline Party membership & 1.03 \\
\hline
\end{tabular}

Sources: Authors' calculations

When asked about their view of their future standard of living compared to that of their parents' peak (Q9), over three-quarters $(77 \%)$ believed that their future standard of living would be better than that of their parents. Only 14\% expected their standard of living to be about the same and 5\% thought they would be worse off than their parents. Four percent were not sure. The Pearson correlation test indicated that there is a significant difference between the responses most frequently given (Pearson's $r=0)$. The KruskalWallis test suggested that there is no significant difference between the students' perception of their families' social class and their view of their expected standard of living as compared to that of the peak of their parents (p-value 0.766). These results suggest that Chinese educated youths hold very positive views of their futures and their beliefs in obtaining middle class status.

We also queried the students on their views of the future of China's economic growth (Q10). Most of them were optimistic about the long-term future of China's economic growth, with $89 \%$ saying that they were at least somewhat optimistic if not very optimistic. This optimism does not seem to depend on the students' perceived view of their families' social class (the p-value in the Kruskal-Wallis test was 0.058). Only 11\% were somewhat or very pessimistic. The students overwhelmingly believed that the middle class in China is growing (72\% said so). Only 14\% said that it was static and $6 \%$ answered that it was declining. An additional 8\% did not know. The Pearson correlation test that was run for both questions to test the relationship between two responses with most frequent answers indicated a statistically significant difference (Pearson's $r=0$ ). These results also demonstrate Chinese college students' positive attitudes toward their own future and their expected place in the middle class. The students see themselves rising with the expanding middle class.

The survey also asked two questions about motivation for a university education and plans after obtaining the degree (Q12 and Q13). Over half (51\%) said that they went to college to get a good job and one-quarter $(25 \%)$ said they wanted to learn more (Pearson's $r=0$ ). Fourteen percent said they went to college to become successful and additional 3\% were pushed by their parents' will. As for their plans after graduation, about one-third (31\%) said they wanted to apply to graduate schools; slightly more preferred to apply to a university outside of China (17\% vs. 14\%). Thirteen percent wanted to find a job in a private sector and 24\% wanted to find a job at a financial company or bank. Only $12 \%$ wanted to work for the government or a state owned enterprise and similarly only five percent wanted to run their own business or company. This documents the change in attitudes of students about making it in the private sector and gaining further post-graduate education and the de-emphasis of students' interest in working for the state.

An additional question (Q20) in our survey asked about growth opportunities for Chinese youth versus American students in the next decade. About one-third (32\%) were not sure who would have better opportunities and much fewer $(18 \%)$ believed that Chinese and American youth would have about the same growth opportunities (Pearson's $r=0$ ). Another quarter felt that American youth would have better growth 
opportunities and slightly more $(26 \%)$ thought that Chinese youth would. The results do not necessarily indicate that the Chinese students were pessimistic about their future. Rather, this might be a reflection of Chinese culture that emphasizes modesty and moderation in all aspects of life, which includes the youths' future expectations.

Two questions (Q17 and Q18) probed the possible perceived impact of the rise of the middle class on future economic, social and political changes in China. Most students believe that these changes are imminent as the middle class is gaining strength. Slightly less than half (47\%) strongly agreed with the statement that "China's growing middle class could contribute to economic changes in China" and another $48 \%$ agreed with the statement (Pearson's $r=0)$. Slightly more $(54 \%)$ somewhat agreed that the growth of the middle class could have an impact on social and political changes but only one-third (33\%) strongly agreed (Pearson's $r=0$ ). So, in general, the vast majority of students believe that there was some possibility that the middle class could influence economic, social and political changes in China.

One final question asked about the students' perception of the impact of the growing middle class on Chinese people's beliefs and viewpoints (Q19). One-third strongly believed that the Chinese will become more interested in having individual civil rights. (These results included those who selected multiple answers). A little less than one-quarter (22\%) felt that the Chinese would become more individualistic and almost a quarter perceived that they would become more interested in Western type democracy (23\%). and freedom. Only 16\% thought that they would become more political and even less (only 6\%) thought that they would become less interested in community. So based on the results from this question, some of China's educated youth believe that the middle class might become more Western (i.e., individualistic and focused on civil rights and interested in a Western style democracy).

It is important to compare our survey results with other quantitative studies of the characteristics and viewpoints of the middle class in China. This allows us to see if what we found in the perceptions of new undergraduates relates to the views of the general population and business and opinion leaders in China. One of the most comprehensive surveys of Chinese views on their world and future is provided by the Committee of 100 (2013) surveys. The Committee of 100 (C-100) is a national non-partisan, non-profit membership organization comprised of prominent Chinese Americans in a broad range of professions. The C-100 Opinion Survey questions business leaders, opinion leaders and the general public about their views of the middle class. We will focus on a comparison of their results in the 2012 Survey on Chinese Domestic Views to our survey of Chinese students. A second major study was conducted by Chen (2013) using data from a probability-sample survey and a set of in-depth interviews conducted in three Chinese cities, Beijing, Chengdu, and Xi'an, in 2007 and 2008.

One of the issues that we investigated in our study was how educated youth in China define the middle class. Contrary to mainstream studies that find income, occupation and education to be major characteristics, Chen (2013) concludes that the occupation-based measure is a more reliable and practical indicator of the middle class. Our survey of the students in Shanghai indicates that the students perceived the middle class differently. More than one-third thought that the level of education (having a university degree) was the definitive characteristic. A slightly lower number $(32 \%)$ considered median household income level to be a signal of the middle class. So, we found that students do not perceive occupation as the critical factor but rather a combination of income and education.

In our survey we asked the students about their views of the key attributes of being middle class. The three characteristics that were deemed "very important" by at least two-thirds of the students were: having a secure job (75\%), ownership of a home or apartment (78\%), and having health insurance (66\%). The ones that were deemed somewhat important by about half of the students were: ownership of stocks, bonds or other investments (53\%), ability to buy designer clothes (49\%), having a college education (48\%), owning a $\operatorname{car}(47 \%)$ and having the ability to travel a lot $(48 \%)$. The one attribute that showed a much more split view 
was "having the freedom to do what they want." Slightly more than half $(52 \%)$ perceived this as an attribute of being middle class but another 39\% thought that it was only somewhat important.

When considering the main personal life goals of the Chinese public, the C-100 survey revealed that wealth and family were the two top goals. Almost half of the respondents from the public answered that their goals were "to get rich" (49\%) and "to have a happy family life" (45\%). The next two most important responses were "to live as I like" (33\%) and "to enhance their social status" (25\%). In a similar question in our survey about the students' most important personal goal in life, surprisingly three answers stood out: "to live as I like" (43\%), "to have a happy family" (20\%), and to have a "successful career" (14\%). All of the others were only listed by $10 \%$ or less of students, including "enhancement of social status," "get rich," and "work on behalf of society" $(10 \%, 2 \%$, and $1 \%$, respectively).

The C-100 survey also asked about the future opportunities for Chinese youth. The question was whether the respondents thought that the youth of China would have better growth opportunities in China or in the U.S. Approximately one-third of the three surveyed groups thought that they would have better opportunities in China. In contrast, only the business leaders (47\%) believed that Chinese youth would have better opportunities in the U.S. In our survey, the students had a much more moderate view of the comparative opportunities of Chinese students relative to those of American students. The results split evenly at about 25\%, as to whether they would do better than American students or that the Americans would.

The C-100 survey also asked how the respondents viewed the future of China. Specifically, the survey asked if China "is headed on the right track" or "are things headed on the wrong track." A large majority of the Chinese public (74\%), opinion leaders (65\%) and business leaders $(72 \%)$ thought that China is on the right track. When we asked our students about their perceptions of the future for China, about 53\% said they were somewhat optimistic and another 36\% were very optimistic (Pearson's r $=0$ ). So, there was general agreement in the comparison of the two survey results, though, once again, the student response was somewhat more moderate.

There is a general belief in the Western world that a rising middle class often leads to economic, political and social changes. In the C-100 survey, two-thirds of business leaders surveyed and a majority of opinion leaders $(57 \%)$ strongly agreed or somewhat agreed that China's middle class could contribute to social and political changes. Less than half $(44 \%)$ of the public felt this way. The views of the students in our survey were stronger and more optimistic than those of the business and opinion leaders and definitely differed from the much less positive views of the Chinese public $-95 \%$ of the respondents strongly agreed or somewhat agreed that the middle class could contribute to economic changes in China. But, in contrast, students were less certain about the impact of the rise of the middle class on social and political order. Only slightly more than a half (54\%) somewhat agreed. So the students think that the rising middle class will have more of an impact on economic changes than social and political ones, the result that supports our original hypothesis.

There is an ongoing debate about the nature and potential impact of the middle class in China as compared to that in Western countries. Chen (2013) argues that the new middle class in China is very different from the middle classes in the West because of its heavy reliance on the state for its survival and growth. Yang (2010) sees China's rising middle class as a stabilizing influence in Chinese society. It generally has a more positive attitude about democracy and high expectations of social justice, but it has benefited from the economic growth of the nation and gained their current lifestyle through the policies and programs of the state. Therefore, Yang concludes that they are more conservative and more supportive of the state and seek economic security and socio-political stability.

In contrast to Chen and Yang, Barton, Chen and Jin in "Mapping China's Middle Class" (2013) describe the new rising urban middle class as becoming much more westernized. The most striking group of the 
various recent generations of middle class is what they call "Generation 2." It comprised nearly 200 million consumers in 2012 and accounted for 15 percent of urban consumption. In ten years' time, their share of urban consumer demand should more than double to $35 \%$. The students surveyed in our study, in fact, belong to Generation 2. They were born after the mid-1980s and raised in a period of the 1980s when China was opening up to the world. McKinsey research (Barton et al., 2013) has shown that this generation of Chinese consumers is the most westernized to date in China. They are confident, independent minded and determined to display that independence through their consumption of Western products. As an indication of their attitude toward the state, the students in our survey placed much more emphasis on developing a career in the private sector and much less interest in working for the state.

\section{CONCLUSION}

This paper provides insights into the perceptions of a sample of undergraduate students in Shanghai on the characteristics and impact of the rise of the middle class in China. It uses a survey research methodology to gain the perceptions of the next generation of educated youth in China and the potential impact of the middle class on the future of China. Moreover, it compares the perceptions of the students surveyed to other studies analyzing the points of view of China's general public, opinion leaders and business leaders, as well as growing and modernizing urban populations in China.

The results of our study demonstrate that students who were surveyed have somewhat different views of the middle class and its future role as compared to those found in other studies. While most of the existing research suggests that occupation is the defining characteristic of the middle class, the students in our survey mostly use education (university degree) and median income as the two key characteristics. The students believe that the middle class is growing in China and expect it to continue to do so in the future. They also expect to be a part of this growth. Almost one-half of the students already feel that their families are middle class. Another quarter thought their families were above middle class. These views are similar to the views of China's general public and its elites that were found in previous studies. This allows us to begin to draw more general conclusions based on the results we have obtained, even though our sample is relatively small and comes from one university in Shanghai.

The most evident difference seen in our students' views versus more traditional viewpoints is on the role of the middle class in Chinese society. There appears to be a sharp contrast between the traditional view of a conservative middle class that is supportive of the state and our survey results. The university students in Shanghai are much more oriented toward opportunities in the private sector and much less interested in seeking state employment. This indicates a possible alternative view for the future role of the middle class in China. The current younger generation is much more westernized and seems to have values that are much more individualistic. Combined with the emphasis on making their careers in the private sector, this suggests that they may at least advocate for more privatization in China, if not a push towards more individual rights and freedoms. This perception contrasts with the traditional view expressed in the literature that the success of China's middle class is very much intertwined with the state and its policies. Therefore, it has been much more conservative politically about advocating social and economic change. If this new generation pursues its goals, the future middle class may consider the role of the state to be less important and therefore want more freedom and fewer regulations by the state.

Given the perceptions of the educated youth of China, as seen in our survey research, the expectations of the impact of the future middle class would be primarily on consumer behavior, business attitudes, and general economic conditions. The changes in the social order and political structure would be more modest. Yet, this does not mean that the Chinese middle class will become more Westernized. China may follow its own path and the Chinese middle class may take pride in being different. In fact, China's spectacular growth 
has given birth to an impressive number of tech-hungry and free-spending young people who have been driving domestic consumption and entrepreneurial spirit (The Economist, 2017). According to the Economist (2018), the market value of Alibaba and Tencent, Chinese super-giants, is on a par with Alphabet and Facebook, while China's e-commerce sales are twice as high as those in the USA. China is home to some of the boldest entrepreneurs and audacious venture capitalists. The overall worth of its 89 unicorns (start-ups that are valued at $\$ 1 \mathrm{bn}$ or more) is over $\$ 350 \mathrm{bn}$ and is getting close to that in America (The Economist, 2017). This inventive and tech-driven middle class may be much more interested in economic improvement than in the political or social changes, especially if it continues getting support from the state.

Although this is a case study of Shanghai students only, it opens a pathway to studying the possible impacts of the rise of the middle class in China. We would encourage that more research be done on the up and coming Chinese educated youth to better understand their viewpoints as they progress into becoming part of the new rising middle class in China.

\section{ACKNOWLEDGEMENT}

We would like to thank an anonymous reviewer for the valuable comments and suggestions. We also would like to thank the faculty of the University of Shanghai for Science and Technology for providing us with an opportunity to conduct the survey.

\section{REFERENCES}

Alford, R. R. (1962). A suggested index of the association of social class and voting. Public Opinion Quarterly, 417-425. doi: https://doi.org/10.1086/267115

Barton, D., Chen, Y., \& Jin, A. (2013). Mapping China's middle class. McKinsey Quarterly, 3, 54-60.

Bergère, M. C. (1989). The golden age of the Chinese bourgeoisie, 1911-1937 (p. 5). Cambridge: Cambridge University Press. Blau, R. (2016). "Chinese Society: The New Class War." The Economist $9^{\text {th }}$ Jul: From the print edition.

Brown, D., \& Jones, D. M. (1995). Democratization and the myth of the liberalizing middle classes. In Towards illiberal democracy in Pacific Asia (pp. 78-106). Palgrave Macmillan UK.

Burris, V. (1986). The discovery of the new middle class. Theory and Society, 15(3), 317-349. doi: https://doi.org/10.1007/BF00172232

Centers, R. (1949). The psychology of social classes: a study of class consciousness. Princeton: Princeton University Press.

Chen, J. (2013). A middle class without democracy: Economic growth and the prospects for democratization in China. Oxford University Press.

Chen, J., \& Lu, C. (2011). Democratization and the middle class in China: The middle class's attitudes toward democracy. Political Research Quarterly, 64(3), 705-719.

Chen, J., \& Lu, C. (2006). Does China's Middle Class Think and Act Democratically? Attitudinal and Behavioral Orientations of Middle Class Toward Urban Self-Government. Journal of Chinese Political Science, 110(2). doi: https://doi.org/10.1177/1065912909359162

Chen, J. (2004). Popular political support in urban China. Woodrow Wilson Center Press.

Committee of 100, (2013). US China Public Perceptions: Opinion Survey 2012. New York, NY: Committee of 100.

Dahl, R. A. (1971). Polyarchy: Participation and Opposition (Vol. 54). New Haven, CT: Yale University Press.

Davis, D. E. (2004). Discipline and development: middle classes and prosperity in East Asia and Latin America. Cambridge University Press. doi: https://doi.org/10.1017/CBO9780511499555

Dickson, B. J. (2003). Red capitalists in China: The party, private entrepreneurs, and prospects for political change. Cambridge University Press.

Ekman, A. (2015). China’s Emerging Middle Class: What Political Impact? Asia Visions, 76, 1-38.

Ekman, A. (2014). The Distinctive Features of China's Middle Classes. Asie. Visions, 69, 1-40.

The Economist. (2018). Chinese Tech v American Tech. February 17, p. 61.

The Economist. (2017). The Next Wave: China's audacious and inventive new generation of entrepreneurs. September 23.

The Economist. (2016). Chinese society: The New Class War. Special Report, July 9 ${ }^{\text {th }}$. https://www.economist.com/news/special-report/21701653-chinas-middle-class-larger-richer-and-morevocal-ever-threatens 
The Economist. (2014). Rushing to Join. Print Edition. February 22, 38.

Englehart, N. A. (2003). Democracy and the Thai middle class: Globalization, modernization, and constitutional change. Asian Survey, 43(2), 253-279. doi: https://doi.org/10.1525/as.2003.43.2.253

Eulau, H. (1956). Identification with class and political perspective. The Journal of Politics, 18(2), 232-253. doi: https://doi.org/10.2307/2126983

Fairbank, J. K. (1983). The United States and China. Harvard University Press. p. 51.

Glassman, R. M. (1995). The middle class and democracy in socio-historical perspective (Vol. 10). Brill.

Glassman, R. (1997). The new middle class and democracy in global perspective. Springer. doi: https://doi.org/10.1057/9780230371880

Goodman, D. S. (1999). The new middle class. In The paradox of China's post-Mao reforms (eds. M. Goldman and R. MacFarquhar). (Vol. 12). Cambridge, MA: Harvard University Press, 241-261.

Goodman, D. S. (2016). Locating China's Middle Classes: social intermediaries and the Party-state. Journal of Contemporary China, 25(97), 1-13. doi: https://doi.org/10.1080/10670564.2015.1060757

Huntington, S. P. (1993). The third wave: Democratization in the late twentieth century (Vol. 4). University of Oklahoma press. Johnson, D. L. (1985). Middle classes in dependent countries (Vol. 3). Sage Publications, Inc.

Johnston, A. I. (2004). Chinese middle class attitudes towards international affairs: nascent liberalization? The China Quarterly, 179, 603-628. doi: https://doi.org/10.1017/S0305741004000505

Li, C. (Ed.). (2010). China's emerging middle class: beyond economic transformation. Brookings Institution Press.

Lipset, S. M. (1959). Democracy and working-class authoritarianism. American Sociological Review, 482-501. doi: https://doi.org/10.2307/2089536

Lipset, S. M. (1981). Political man: The Social Bases of Politics (expanded edition). Baltimore, MD: The Johns Hopkins University Press. (first published 1959).

Lu, X. (2002). Research report on social stratification in contemporary China. Beijing, China: Social Sciences Documentation Publishing House (in Chinese). As cited in Chen (2013).

Lu, X. (2004). Contemporary Chinese social mobility. Social Sciences Academic Press, 22-25. As cited in Chen (2013).

Mills, C. W. (1953). White Collar Work: The American Middle Classes. New York, NY: Oxford University Press.

Moore, B. (1993). Social origins of dictatorship and democracy: Lord and peasant in the making of the modern world (Vol. 268). Beacon Press.

Nie, N. H., Powell, G. B., \& Prewitt, K. (1969). Social structure and political participation: developmental relationships, Part I. American Political Science Review, 63(2), 361-378. doi: https://doi.org/10.1017/S0003055400262278

Osnos, Evan. 2013. "Will the middle class shake China?" The New Yorker. 8 March, 1-4.

Sherkat, D. E., \& Blocker, T. J. (1994). The political development of sixties' activists: Identifying the influence of class, gender, and socialization on protest participation. Social Forces, 72(3), 821-842. doi: https://doi.org/10.2307/2579782

Shi, T. (1997). Political participation in Beijing. Harvard University Press.

Silverstein, M.J., Singhi, A., Liao, C., \& Michael, D. (2012). \$10 Trillion Dollar Prize: Captivating the Newly Affluent in China and India, Harvard Business Review Press, Boston, MA.

Song, J., Cavusgil, E., Li, J., \& Luo, R. (2016). Social stratification and mobility among Chinese middle class households: An empirical investigation. International Business Review, 25(3), 646-656. doi: https://doi.org/10.1016/j.ibusrev.2015.04.009

Verba, S., \& Nie, N. (1972). Participation in America: Political Democracy and Social Equality, Nueva York: Harper and Row.

Walsh, K. C., Jennings, M. K., \& Stoker, L. (2004). The effects of social class identification on participatory orientations towards government. British Journal of Political Science, 34(3), 469-495. doi: https://doi.org/10.1017/S0007123404000146

Wang J., \& Davis, D. (2010). "China's new upper middle classes: the importance of occupational disaggregation," in C. Li (Ed.), China's emerging middle class. Beyond economic transformation, Brooking Institution Press, Washington DC.

World Bank. (2018). World Development Indicators. https://data.worldbank.org/indicator.

Wright, E. O. (1997). Class counts: Comparative studies in class analysis. Cambridge University Press.

Yang, J. (2010). Understanding China's middle class and its socio-political attitude. East Asia Policy, 2(4), 50-57.

Xiaohong, Z., \& Chen, Q. (2010). "Globalization, social transformation and the construction of China's middle class," in C. Li (Ed.), China's emerging middle class. Beyond economic transformation, Brooking Institution Press, Washington DC. 